\title{
EFEKTIFITAS PENGGUNAAN METODE DEMONSTRASI PADA PEMBELAJARAN FIQIH DI MA KAPETAKAN
}

\author{
Arif Rohman Hakim \\ ariefayiep78@gmail.com \\ Universitas Al-Ihya Kuningan
}

\begin{abstract}
ABSTRAK
Cara mengatasi kendala dalam solusi Hal tersebut antara lain: memotivasi siswa, memberikan arahan pelaksanaan pembelajaran Fiqih, meningkatkan infrastruktur untuk mendukung kegiatan belajar mengajar, memberikan evaluasi dan supervisi kegiatan siswa di sekolah, serta menambah jam sekolah. Hasil belajar berbasis data dalam pembelajaran siswa Diperoleh melalui angket yang disebarkan ke banyak subjek survei dari MA Kapetakan, kemudian dikumpulkan dan dianalisis melalui rumus distribusi frekuensi, terlihat bahwa di MA Kapetakan Cirebon, metode demonstrasi digunakan dalam pembelajaran Fiqih sangat efektif dalam kursus berikutnya. Hal ini berdasarkan jawaban dari narasumber pada tabel diskusi, dan terlihat dari kemampuan siswa yang sama-sama dapat memahami pelajaran dan praktik. Kesalahan saat mencoba menulis ulang. Periksa jumlah karakter atau karakter khusus.
\end{abstract}

\begin{abstract}
The ways of constraints in the solution include: preparing students, giving directions for the implementation of fiqh learning, infrastructure for teaching and learning activities, providing results and supervision of student activities in schools, and adding school hours. Data-based learning results in the study of questionnaire students were distributed to many sub-surveys from MA Kapetakan, then and the collection was analyzed through the philosophy of distribution, seeing that in MA Kapetakan Cirebon, the implementation of race in learning Fiqih is very safe in the next program. This is the answer from the speakers at the discussion table, and from the dance performances of students who can both understand and practice. Wrong at the moment re-trading. Large Number of characters or special characters.
\end{abstract}

\section{PENGANTAR}

Pendidikan merupakan upaya sadar yang dilakukan oleh keluarga, masyarakat, dan pemerintah melalui kegiatan belajar mengajar yang dilaksanakan di sekolah maupun di luar sekolah sepanjang hidupnya, agar siswa dapat berperan secara tepat dalam berbagai lingkungan di masa yang akan datang (Nurhayati, Fadilah, \& Mutmainah, 2014, p. 2).

Upaya perbaikan metode pengajaran telah berlangsung lama, dan masih berlangsung di beberapa lembaga pendidikan dan sekolah biasa. Biasanya, bisnis ini tidak terorganisir, yang satu tidak memiliki hubungan dengan yang lain (Fathoni, 2020, p. 194). 
Kegiatan belajar merupakan suatu proses pendidikan yang memberikan kesempatan kepada siswa untuk mengembangkan potensi dirinya menjadi kemampuan yang terus berkembang, yaitu sikap, pengetahuan dan keterampilan yang dibutuhkan untuk berkontribusi bagi kesejahteraan umat manusia sebagai negara yang hidup dalam masyarakat (Nurdiana \& Asiyah, 2020, p. 2).

Perubahan merupakan suatu hal yang harus terjadi di bidang pendidikan.Untuk melaksanakan pendidikan yang bermutu, pemerintah telah merumuskan kurikulum 2013 untuk diterapkan di sekolah atau sekolah agama. Tentunya pelaksanaan mata kuliah ini dilakukan secara bertahap (Nurdiana \& Asiyah, 2020, p. 2).

Sebagai guru yang profesional di bidang pendidikan, selain pemahaman Hal filosofis dan konseptual juga harus mengetahui dan mengimplementasikan masalah teknis. Hal-hal teknis tersebut terutama untuk mengatur dan melaksanakan interaksi belajar mengajar (Dhin, 2017, p. 171).

\section{PEMBAHASAN}

Efektivitas pembelajaran menggunakan metode demonstrasi terhadap prestasi belajar siswa diperlihatkan dari perhitungan rata-rata prestasi belajar siswa, yaitu persentase pencapaian siswa dalam postest 2 dibanding postest 1 pada kelompok eksperimen dan kontrol (Situmorang \& Situmorang, 2013, p. 34).

Efektivitas mengacu pada seberapa besar kelekatan keluaran yang dapat dicapai oleh keluaran yang diharapkan dari banyak masukan (Afriyadi, 2015, p. 363).

Dari beberapa pengertian di atas dapat diambil kesimpulan bahwa Efektifitas adalah suatu kegiatan yang direncanakan tepat pada waktu atau sasaran.

Metode demonstrasi adalah metode pengajaran mata kuliah dengan cara sebagai berikut: Peragakan dan peragakan kepada siswa proses, situasi atau objek tertentu, baik aktual maupun yang hanya ditiru.

Ciri-ciri metode demonstrasi dilakukan:

1. Apabila akan membrikan keterampilan tertentu

2. Untuk memudahkan berbagai penjelasan, sebab penggunaan bahasa dapat lebih terbatas

3. Untuk menghindari verbalisme

4. Untuk membantu anak memahami dengan jelas jalanya suatu proses dengan penuh perhatian sebab akan menarik

Seperti yang bisa dilihat dari penjelasan di atas, di Jika materi menggambarkan suatu keterampilan tertentu, maka apa yang harus dilakukan akan membuat siswa tersebut lebih muda.

Setiap aktivitas yang dilakukan pasti ada tujuannya. Juga Memiliki metode demonstrasi yang berkaitan dengan pendidikan atau pengajaran. Tujuan metode demonstrasi dalam proses pembelajaran adalah untuk memperjelas pemahaman konsep dan menjelaskan bagaimana melakukan sesuatu atau proses terjadinya sesuatu. 
Metode demonstrasi sebagai metode pengajaran khusus Dalam kegiatan pengajaran khususnya bidang Fiqih, fungsi yang diharapkan antara lain:

a. melalui mendengarkan penjelasan lisan, pemahaman yang jelas tentang proses atau keterampilan konsep ilmiah FIQIH secara mendasar.

b. Perlihatkan kepada siswa dengan jelas langkah-langkah keterampilan berdoa.

Kelebihan Metode Demonstrasi

1. Siswa akan memiliki pemahaman yang lebih jelas tentang jalannya hal-hal yang ditampilkan.

2. Perhatian siswa akan lebih mudah untuk fokus pada hal-hal penting yang sedang dibahas

\section{Kelemahan Metode Demonstrasi}

1. Apabila demonstrasi tidak digunakan secara matang maka bisa terjadi demonstrasi banyak kesulitan.

2. Kadang-kadang sesuatu yang di bawa ke kelas untuk didemonstrsikan terjadi proses yang berlainan dengan proses yang terjadi dalam situasi yang sebenarnya.

Tentang judul penelitian penulis, penulis Masukkan objek penelitian di MA Kapetakan Cirebon. Atas tuntutan orang tua/wali murid serta masyarakat khususnya kaum muslimin yang didorong rasa pentingnya pendidikan yang bernuansa Islam, maka terketuklah hati para ulama serta tokoh masyarakat untuk perlu menyelenggarakan suatu pendidikan tingkat menengah atas, yang berNuansa Islami.

Dalam perkembanganya sampai sekarang Madrasah Aliyah Kapetakan Kabupaten Cirebon telah berusia lebih dari 37 tahun. Memperhatikan perkembangan sistem pendidikan nasional tahun 1970 dan kebutuhan masyarakat, serta untuk menampung lulusan MTs dan SMP yang akan melanjutkan ke tingkat SLTA, maka pada tanggal 1 Juli 1983 Masehi, Yayasan Pendidikan Islam Wilayatullah mendirikan Madrasah Aliyah Kapetakan Kabupaten Cirebon, di bawah binaan Departemen Agama RI Madrasah Aliyah Kapetakan Kabupaten Cirebon adalah salah satu lembaga pendidikan setingkat SLTA yang dapat disebut SMA berciri khas Islam.

Ciri khas Islam yang dimaksud karena program kurikulum Pendidikan Agama lebih dijabarkan seperti pelajaran Al-Qur'an Hadits, Akidah Akhlak, fiqih, Bahasa Arab, dan khusus keterampilan agama. Plus bagi Madrasah Aliyah Kapetakan 
Kabupaten Cirebon siswa dibekali ketrampilan computer, ketrampilan Bahasa Jerman, Kerajinan Tangan, Olah Raga, seni, dan Bimbingan Karir.

Melihat rumusan masalah yang dibuat oleh penulis, maka dalam hal ini penulis akan membahas rumusan masalah dalam penelitian ini, tentang :

1. Penerapan metode demonstrasi dalam meningkatkan pemahaman siswa terhadap pembelajaran bahasa, yaitu melalui penggunaan berbagai metode yang sesuai dengan materi yang dibahas dan sesuai dengan situasi dan kondisi siswa. Beberapa jenis metode yang biasa kita gunakan antara lain ceramah, tanya jawab, demonstrasi, dan media yang digunakan sebagai sumber belajar dalam pembelajaran Fiqih Islam tentunya akan disesuaikan dengan karakteristik materi yang akan diajarkan dan tujuan pembelajaran yang ingin dicapai. Misalnya untuk materi yang menjelaskan tentang ketentuan Ha dan shalat korban / tata cara, jenis media yang sering digunakan adalah media cetak, seperti buku teks dan LKS, guru dan siswa itu sendiri. Jenis media audiovisual, seperti menggunakan CD player dengan memutar beberapa kaset program qurban yang sesuai atau menempelkan gambar di papan tulis.

2. Hambatan dalam penerapan metode demonstrasi berasal dari berbagai sumber. Berdasarkan hasil wawancara dan observasi, terdapat beberapa faktor yang menghambat penggunaan metode demonstrasi. Pembelajaran guru meningkatkan pemahaman siswa selama kegiatan belajar mengajar. Siswa telat, suasana kelas ramai, sarana prasarana terbatas, waktu terbatas, kondisi psikologis siswa dan faktor lingkungan.

\section{KESIMPULAN}

Cara mengatasi kendala dalam solusi Hal tersebut antara lain: memotivasi siswa, memberikan arahan pelaksanaan pembelajaran Fiqh 24, meningkatkan infrastruktur untuk mendukung kegiatan belajar mengajar, memberikan evaluasi dan supervisi kegiatan siswa di sekolah, serta menambah jam sekolah. Hasil belajar berbasis data dalam pembelajaran siswa Diperoleh melalui angket yang disebarkan ke banyak subjek survei dari $17 \mathrm{~V}$ siswa, kemudian dikumpulkan dan dianalisis melalui rumus distribusi frekuensi, terlihat bahwa di MI PUI Jatisawit Lor Kec. Jatibarang Kab. Pada tahun ajaran 2011 Indramayu, metode demonstrasi digunakan dalam pembelajaran sejarah peradaban Islam. -2012 sangat efektif dalam kursus berikutnya. Hal ini berdasarkan jawaban dari narasumber pada tabel diskusi, dan terlihat dari kemampuan siswa yang sama-sama dapat memahami pelajaran dan praktik. 


\section{Bibliografi}

Afriyadi, Ferry. (2015). Efektivitas Komunikasi Interpersonal Antara Atasan dan Bawahan Karyawan PT . BORNEO ENTERPRSINDO SAMARINDA. Manajemen Komunikasi, 3(1), 362-376.

Dhin, Cut Nya. (2017). Pelaksanaan Pakem Dalam Pembelajaran Fiqih Pada Min Seutuy Kota Banda Aceh. PIONIR: Jurnal Pendidikan, 5(1).

Fathoni, Ahmad. (2020). PADA PEMBELAJARAN FIQIH. 6(1), 193-201.

Nurdiana, Nurdiana, \& Asiyah, Siti. (2020). Implementasi Pendekatan Saintifik Pada Pembelajaran Fiqih di Madrasah Aliyah Negeri (MAN) Kota Kupang. Al Manar: Jurnal Pendidikan Islam, 2(1), 1-12.

Nurhayati, N., Fadilah, Syarifah, \& Mutmainah, Mutmainah. (2014). Penerapan Metode Demonstrasi Berbantu Media Animasi Software Phet terhadap Hasil Belajar Siswa dalam Materi Listrik Dinamis Kelas X Madrasah Aliyah Negeri 1 Pontianak. Jurnal Penelitian Fisika Dan Aplikasinya (JPFA), 4(2), 1-7.

Situmorang, Hamda, \& Situmorang, Manihar. (2013). Efektivitas Metode Demonstrasi Dalam Meningkatkan Hasil Belajar Siswa Sekolah Menengah Kejuruan Pada Pengajaran Sistem Koloid. Jurnal Penelitian Bidang Pendidikan, 19(1), 28. https://doi.org/10.24114/jpp.v19i1.3044 